\title{
Cross Analysis of the Case Studies
}

Our methodological innovation, ethnography of Europeanization, offers a multi-dimensional and intersectional approach to how people construct Europe and their notion of belonging to it at different social and cultural locations. We explore this in data sets from three EU cultural initiatives - the European Capital of Culture (ECOC), the European Citizen Campus (ECC), and the European Heritage Label (EHL). In our three case studies, various social locations and demographic aspects, such as age, gender, education, nationality, country of residence, and level of active engagement in cultural participation, had a major impact on our research participants' answers dealing with Europe and the 'European'. These socio-demographic factors affected both people's agency and their imaginations of Europe, and intersected with other social and cultural phenomena that participants addressed, such as mobility, cultural diversity, and ideas of participation. People's social location plays a role in deepening and/or creating opportunities for engaging in such phenomena and contributing to processes of belonging.

In this chapter, we bring together the core findings from our three case studies and cross-analyze them in relation to spatial and temporal contexts, including the specific contexts in which the EU cultural initiatives occurred. While we address the overlap in our data, we have no intention to conduct a comparative study. Our qualitative analysis takes into account only the answers of EU citizens and of citizens of Russia, Ukraine, and Switzerland, which includes all respondents and participants in the ECOC and ECC data sets and 230 interviewed visitors to EHL sites.

In order to interpret and understand our data and its meanings more extensively, we have quantified certain answers from our interviews and survey. These findings are valid and representative only for the respective case study in which the responses were collected. Bearing in mind the small numbers of informants, particularly in the ECC and EHL cases, we do not claim that our results are as representative as larger surveys like Eurobarometer. However, grouping the answers enabled us to discuss belonging to Europe from different perspectives and in various contexts, and to consider the factors affecting the answers that referred to the respondents' relationship to Europe and views on the 'European'. Grouping answers also helped us to identify important topics 
in the debates about Europe and belonging to it. While our findings suggest a connection between European identity and support for European integration, we noted that this was not the case for all interviewees and respondents, some of whom either considered themselves European but were critical of the EU's policy or who rejected the idea of a European identity but were nevertheless supportive of the Union's policy and goals. This suggests that a variety of factors, including the extent of transnational experiences, are important determinants that influence people's self-identification as European and their support for European integration (see Kuhn 2011, 2019, 1215). In our discussion, we relate our participants' social locations and backgrounds to how they constructed Europe and the 'European'. The analysis allows us to link their views and backgrounds to various cultural and social phenomena occurring in Europe in the 2o10s.

\section{The Impact of Social Locations and the Research Setting on} Notions of Europe

\subsection{Gender}

In all our three case studies (Chapters 4-6), more women than men participated in the questionnaire surveys or qualitative interviews. Although we are aware of more than binary gender conceptions, we did not perceive any potential conflict based on the traditional gender division during our data collection and we will therefore continue to refer to men and women only. In the ECOC data, eight respondents did not (for several possible reasons) reveal their gender. Based on our data, we noticed that female participants and interviewees tended to hold neutral to positive views on the 'European' and Europe more often than men did, particularly participants in the ECOC and EHL case studies (see tables 7.1 and 7.2). The ECC case is slightly different as all interviewees had volunteered to participate in a European project with thematic workshops dealing with European issues, and we therefore assume that the participants had positive associations with Europe and the EU. While male interviewees and respondents also had a high approval of Europe and the EU, in particular on economic and political issues, they more often voiced criticism towards the EU and its current state of affairs and politics in their answers.

Drawing on our EHL interview data, more women than men expressed the view that something like a European identity might exist and it seemed to be easier for women to describe what this was (see Table 7.1). They often connected it to notions and ideas that highlighted family and roots on the one hand, and the importance of peace and strengthening rights and equality, on 
the other. In contrast, among these interviewees, men were more often critical of the whole concept of European identity, or approached it from a constructivist perspective, as a project, or as something still under construction that may emerge in the future. Very few interviewees of each gender (i.e. seven or less) either had negative associations with European identity or did not think that a European identity exists, so we cannot say anything valid based on these numbers. However, as the EHL data shows, gender had an impact on the ability to construct notions of what represents Europe and the 'European', which in turn may contribute to less negative associations with the concept of European identity.

TABLE 7.1 Notions of European identity and feeling European in relation to gender among EHL visitors from EU countries, Russia, Switzerland, and Ukraine (123 women and 107 men)

\begin{tabular}{|c|c|c|}
\hline & Women & Men \\
\hline Strongly feels European & $62 \%$ & $66 \%$ \\
\hline $\begin{array}{l}\text { Feels both European and membership of a specific nation, } \\
\text { region, or city }\end{array}$ & $22 \%$ & $21 \%$ \\
\hline Does not feel European & $13 \%$ & $10 \%$ \\
\hline Positive associations with the concept of European identity & $19 \%$ & $19 \%$ \\
\hline Neutral associations with the concept of European identity & $64 \%$ & $50 \%$ \\
\hline Negative associations with the concept of European identity & $6 \%$ & $9 \%$ \\
\hline $\begin{array}{l}\text { Other associations with European identity (e.g. views that } \\
\text { it is a project, still needs elaboration, or may emerge only in } \\
\text { the future) }\end{array}$ & $11 \%$ & $22 \%$ \\
\hline Is able to describe what European identity is & $65 \%$ & $51 \%$ \\
\hline Does not think that European identity exists & $7 \%$ & $17 \%$ \\
\hline
\end{tabular}

In the following, we refer to our detailed analysis of the ECOC case as an example that supports the findings on the interrelation between gender and views of Europe from our E HL case. The questionnaire survey used in the ECOC study allowed us to cross-reference gender with respondents' views on Europeanness. Our analysis of the ECOC case indicated that women identified with Europeanness more often than men (see Table 7.2). When calculating how much the respondents considered Europeanness as an important element for their identity, women had a higher score in all case Ecocs (mean score of a scale of 1-3 [not at all / to some extent / a lot]: for respondents in Pécs, women 
2.47 and men 2.24; Tallinn, women 2.43 and men 2.32; Turku, women 2.28 and men 2.27). The difference between genders was biggest in Pécs and smallest almost equal - in Turku. The data analysis also suggested that women had more positive perceptions of the concept of Europeanness. The mean score of a scale of $1-5$ (very negative / negative / neutral / positive / very positive) for women was higher in all case Ecocs (Pécs women 3.90 and men 3.75; Tallinn women 4.11 and men 3.93; Turku women 4.07 and men 3.93). We noted that in this score, the difference between genders was biggest in Tallinn and smallest in Turku.

TABLE 7.2 Views on Europeanness among the respondents from Pécs, Tallinn, and Turku based on gender ( 968 women and 451 men)

\begin{tabular}{|c|c|c|}
\hline & Women & Men \\
\hline Identifies a lot with Europeanness & $44 \%$ & $38 \%$ \\
\hline Positive or very positive impressions on Europeanness & $76 \%$ & $70 \%$ \\
\hline $\begin{array}{l}\text { Sees that ECOC events represent a lot or very much } \\
\text { Europeanness }\end{array}$ & $63 \%$ & $55 \%$ \\
\hline $\begin{array}{l}\text { Sees that ECOC events should represent a lot or very } \\
\text { much Europeanness }\end{array}$ & $74 \%$ & $67 \%$ \\
\hline
\end{tabular}

The respondents' views on how the Ecoc events represented Europeanness, or how they should represent it, followed similar gender bias. We calculated how much the respondents perceived that the ECOC events represented Europeanness using the mean score on a scale of ${ }^{-1} 5$ (not at all / a little / to some extent / a lot / very much), and found that women scored higher than men (Pécs women 3.82 and men 3.68; Tallinn women 4.01 and men 3.64; Turku women 3.68 and men 3.58). Here, the difference was biggest again in Tallinn and smallest in Turku. Moreover, women saw more often than men that the events should represent Europeanness (in Pécs women 4.15 and men 3.96; Tallinn women 4.22 and men 4.01; Turku women 3.78 and men 3.69). Again, the biggest difference was in Tallinn and the smallest in Turku.

These geographical differences in our findings on gender and Europeanness are difficult to explain but may connect to the influence of broader social and cultural phenomena, such as the experience, attributed significance, and implementation of gender equality. We found that in Pécs and Tallinn, both the ECOC programmes and the ECOC audiences often emphasized and dealt with the aim and interest of 'becoming' and being taken more seriously as 
European. Although EU integration has increasingly extended to various societal sectors since the Eastern enlargement of the Union, the old division of Europe into 'East' and 'West' continues to influence notions of Europe. The Central and Eastern European countries that joined the EU in 2004 and 2007 have not been always perceived to be as European as their Western counterparts (Lee and Bideleux 2009). Many of these countries have, therefore, sought to 'become' more European. Cities have used the ECOC action as a tool to become better-known as European on a wider European and global scale. However, becoming European has proved challenging for many smaller Central and Eastern European cities, as it has been equated with modern infrastructure and the polished appearance of city space. The ECOCs in Eastern and Central European countries have also aimed to broaden the whole notion of the 'European' by narrating their socialist history, heritage, and experience as part of it. Both in Pécs and in Tallinn, the EcOC programme included this historical layer and heritage in their 'European dimension' but this layer was not emphasized in the audiences' responses on the 'European'.

The findings from the ECOC data suggest a connection between Europeanization and the political and socio-cultural traditions in the respective countries. Compared to Estonia and Hungary, Finland has a longer tradition of gender equality dating from the introduction of women's right to vote and stand for election in 1906. With other Nordic countries, Finland is commonly perceived to score high on gender equality politics (Lähdesmäki and Saresma 2014). Unlike the former Eastern bloc countries - Estonia and Hungary - Finland was more strongly influenced by EU politics, even before becoming member state. The European Community and then Union has emphasized equality between men and women as a fundamental value and sought to advance gender equality from its beginnings (Jacquot 2015; EC 2019; see also Lähdesmäki et al. 2020). While broad public discussion of women's rights and gender equality began in Western countries in the late 196os, this did not occur in the Soviet Union and its satellite states, even though the communist imagery and rhetoric characterized women as 'equal to men', emphasized the importance of women in the society, and offered greater opportunities and expectations for them to participate in the workforce. This different development may have shaped each society's dominant perceptions on gender. In turn, it influences people's relations and associations with Europe.

Thus, gender and the experience of gender politics may be more relevant for forming people's views on Europe and their relationship with the EU in some societal contexts than in others. The extent and ways in which certain social phenomena are addressed in societies can reflect their citizens' views on Europe as a whole. Social environments and the experience of everyday life 
and practices are relevant to how people construct their relations with Europe, their expectations of the EU, and their views on the desirability of 'Europeanness'. In countries where gender rights are more of an issue, Europeanization may become intertwined with attempts to change the perceived status quo and to strengthen women's social and political positions. This may result in a higher approval of Europeanization among women, as indicated in our ECOC data. In contrast, in countries where there is a broad public perception of gender equality, like in Finland, gender may have less impact, and the difference between women's and men's views on Europe may be influenced by other factors than gender.

\subsection{Age}

Another factor that affected the interviewees' and respondents' views on Europe and 'the European' was their age. In the ECOC data, respondents to the questions on Europeanness born in the 1970s and 196os were more reserved towards it than younger or older respondents (see Figure 7.1). The youngest respondents, born in the 1990s or later, and the oldest ones, born in the 1950s or earlier, had the most positive attitude towards the 'European'.

We noted similar findings in the $\mathrm{EH} \mathrm{L}$ data, although this was collected seven years later - the ECOC data was collected in 2010 and 2011 and the EHL data in 2017 and 2018. However, the ECC data was less conclusive on age, as the interviewees were all younger (students) and had consciously decided to participate

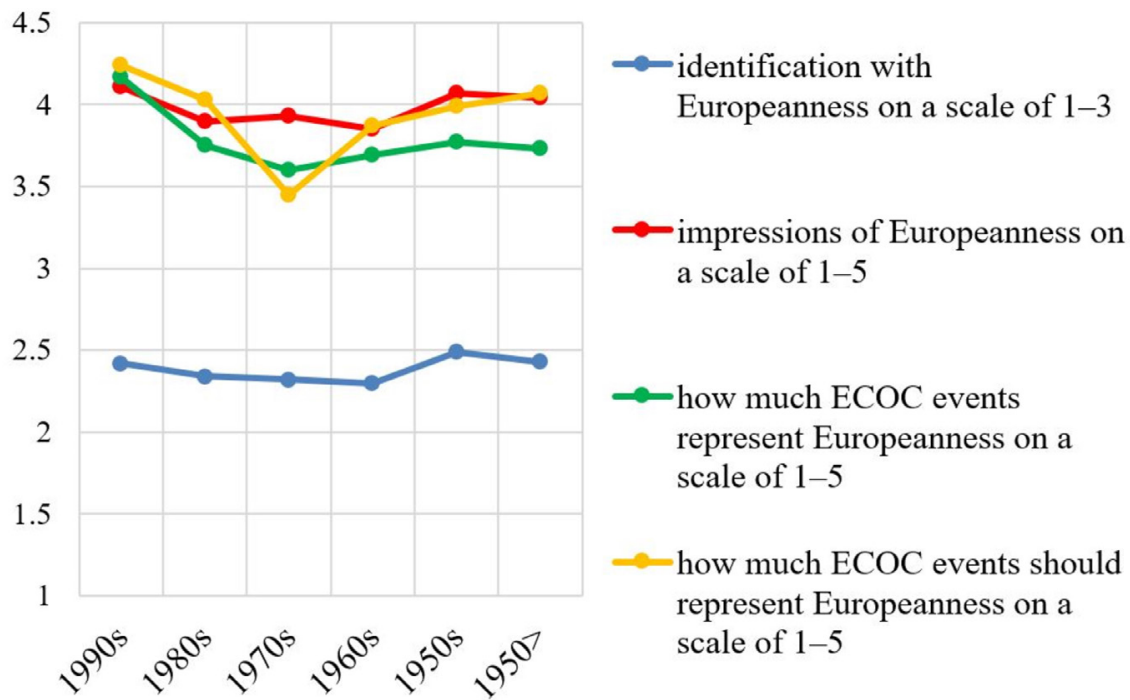

FIGURE 7.1 Views on Europeanness among the ECOC respondents $(\mathrm{N}=1,425)$ from Pécs, Tallinn, and Turku based on age 
in a programme on Europe and the EU. Thus, their higher identification with and sense of belonging to Europe did not come as a surprise (see Chapter 5). Nevertheless, the ECC data shows that younger people who have grown up as EU citizens consider Europe and the EU as relevant topics but have a different way of accessing them, as outlined in our EHL case study (see Chapter 6).

Based on our analysis of the interviews from the EHL sites (see Chapter 6) we divided visitors into three age groups: young (aged 18-35), middle-aged (aged $36-65$ ), and older (66+). In general, high numbers of people in all age groups felt European (in response to the question 'Do you feel European?', see Table $7 \cdot 3$ ). Among young interviewees, $6 \circ \%$ strongly felt European, while $24 \%$ considered themselves both European and national citizens - and sometimes also felt belonging to a certain region or city. In the group of middle-aged interviewees, $64 \%$ strongly felt European and $22 \%$ both European and a national citizen, while in the oldest age group, $74 \%$ felt strongly European, $16 \%$ both European and national citizens, and only four interviewees did not feel European. The younger the age group, the more positive the associations with European identity (young: $24 \%$, middle-aged: $20 \%$, older: $8 \%$ ), while older interviewees seemed to have more negative associations with the idea of a European identity. Older interviewees also more frequently highlighted European identity as a project. To a certain extent this resonates with the findings that the two younger age groups were both better able to describe what a European identity represented and more ready to accept that a shared European identity existed.

This relationship between age and feeling European was slightly surprising to us. Similarly to the ECOC data, younger and older visitors to the EHL sites generally spoke in far more positive terms about European identity and the $\mathrm{EU}$ in the interviews. Middle-aged visitors generally voiced more frequent and often harsher criticism of the EU and the notion of a unified Europe. However, middle-aged interviewees were more likely than young people to give positive responses to the direct question on feeling European. This is one example of participants' contradicting and contested notions in our case studies. One simplified explanation might be that young people are still in the process of finding their way, while middle-aged people are more critical and looking for immediate solutions to current problems, and members of the older generation are more relaxed and less tense about future projects. Another explanation is that there were unequal numbers of interviewees in each age group in the EHL case.

Our cross analysis showed that the EHL visitors in the youngest age group most frequently had positive associations with European identity $(24 \%$, see Table 7.3), while interviewees aged 66 and over seemed to have more negative associations with the idea of a European identity. Interviewees in the 
TABLE 7.3 Notions on European identity and feeling European in relation to age among EHL visitors from EU countries, Russia, Switzerland, and Ukraine ( $\mathrm{N}$ in age groups from the youngest to oldest: 87,93 , and 46 )

Age group

${ }^{18-35} \quad 36-65 \quad 66+$

\begin{tabular}{llll}
\hline Strongly feels European & $60 \%$ & $64 \%$ & $74 \%$ \\
Feels both European and membership of a specific nation, & $24 \%$ & $22 \%$ & $16 \%$
\end{tabular} region, or city

Does not feel European $\quad 12 \% \quad 12 \% \quad 10 \%$

Positive associations with the concept of European identity $\quad 24 \% \quad 20 \% \quad 8 \%$

Neutral associations with the concept of European identity $\quad 6 \circ \% \quad 57 \% \quad 56 \%$

Negative associations with the concept of European identity $\quad 7 \% \quad 5 \% \quad 12 \%$

Other associations with European identity (e.g. views that $\quad 9 \% \quad 18 \% \quad 24 \%$

it is a project, still needs elaboration, or may emerge only in

the future)

Is able to describe what European identity is

Does not think that European identity exists

$\begin{array}{rrr}61 \% & 62 \% & 44 \% \\ 9 \% & 13 \% & 14 \%\end{array}$

middle-aged visitor group had fewer positive associations with the term and concept of European identity than the young interviewees, despite more strongly feeling European. However, this rejection often circled around the term 'identity', which was regarded as too excluding, rather than the idea of commonalities between Europeans from different backgrounds. We also noticed that the older the visitor, the more often the opinion was voiced that Europe, the 'European', and European identity were not a finished process but still under construction. This view did not affect older interviewees at EHL sites in a negative way, and they more frequently felt European than members of the younger groups. In contrast, younger people seemed to strongly connect the idea of being European to being both national and European citizens. Young and middle-aged Europeans were significantly better at describing what European identity meant to them and they more readily voiced the opinion that something like a shared European identity existed (see Table 7.3). These findings suggest a change in the way in which the EU has become accepted and incorporated in people's social location in recent decades. The younger the age group, the more the EU seems to have become a normal and influential factor in people's everyday and banal practices of belonging in Europe.

Our results indicate that the older generation of Europeans should not be generally considered, or automatically dismissed, as conservative and 
reluctant to belong to Europe and build its unity. As discussed in Chapter 6, this generation has had a reason to work towards European belonging as part of rebuilding and developing European societies and consolidating peace, trust, and welfare in them after World War II - particularly in Western European democracies. For young people in Europe today, the EU, transnational experiences, and everyday exchanges in Europe are part of normality, which assumedly becomes reflected in their positive views on Europe.

When analyzing the views to Europe in different age groups between countries, our data did not indicate clear differences between the 'East' and 'West' of Europe. This can be illustrated by the results from the ECOC case study. When calculating how much the respondents considered Europeanness as an important element for their identity, based on the mean of a scale from 1-3 (not at all / to some extent / a lot), the oldest age group, born in 1949 or earlier, scored highest (2.57) in Tallinn, but the figures were not much lower for Turku (2.40) and Pécs (2.38). The youngest respondents, born in the 199os, also scored highest in Tallinn (2.49) and similarly in Turku and Pécs (both 2.37). The perception of the concept of Europeanness was not clearly different in 'East' and 'West' - at least in the youngest age group. The mean perception of a scale of 1-5 (very negative / negative / neutral / positive / very positive) for the youngest respondents was 4.31 in Tallinn, 4.14 in Turku, and 3.92 in Pécs. Among the oldest respondents, the scores were 4.11 in Turku, 3.93 in Pécs, and 3.9o in Tallinn. However, the number of respondents in this age group was relatively low, so it is not possible to draw meaningful conclusions for this question based on age.

\subsection{Education}

Another important socio-demographic factor affecting our research participants' views on Europe, the EU, and belonging is their educational background. In general, interviewees who participated in the ECC project and an overwhelming majority of visitors to the EHL sites had a higher education. The interviewees from the ECC workshops were all university students, while almost three quarters of the interviewed EHL visitors either held a bachelor's, master's, or doctoral degree (or equivalent diploma) or were university students. In the ECOC data, almost half of the respondents had a university degree (see Annex 1).

As Risse (2004, 256) writes, based on earlier studies, education and income have a positive impact on levels of attachment to Europe (see also Citrin and Sides 2004). According to Risse, attachment to Europe is linked with support for the EU and willingness to cede authority and sovereignty to EU institutions in various policy domains. We acknowledge that our discussions of belonging to Europe are largely based on data gathered from people with a higher 
education and shed less light on the notions of belonging to Europe among people with a lower level of education. Despite this educational bias, we are nevertheless able to discuss a wide range of notions and imaginations regarding Europe and the European among European citizens.

The detailed questionnaire study in the ECOC data enabled more detailed cross-tabulation of the impact of education on the respondents' views. Our analysis indicated that education was a relevant factor in the respondents' identification with Europe and their notions of Europeanness. The respondents with lower levels of education appeared to have also lower interest in Europeanness, and less often connected Europeanness with the ECOC events. The data enabled us to conclude that the higher the educational background of the respondents, the higher their identification with Europe and the more positive their impression of Europe (see Table 7.4). Moreover, identification with Europeanness seemed to reflect ease to interpret the European dimension in the ECOC events (see Lähdesmäki 2013, 2014a).

TABLE 7.4 Views on Europeanness among the respondents from Pécs, Tallinn and Turku based on educational level ( $\mathrm{A}$ = comprehensive or elementary school, vocational course, or in-job training, $\mathrm{N}=155$; $\mathrm{B}$ = high school, polytechnic, or other higher vocational degree, $\mathrm{N}=622 ; \mathrm{C}=$ higher education [bachelor's, master's, or doctoral degree], $\mathrm{N}=630$ )

A B $\quad$ C

\begin{tabular}{|c|c|c|c|}
\hline Identifies a lot with Europeanness & $39 \%$ & $40 \%$ & $44 \%$ \\
\hline Positive or very positive impressions on Europeanness & $69 \%$ & $71 \%$ & $78 \%$ \\
\hline $\begin{array}{l}\text { Sees that ECOC events represent a lot or very much } \\
\text { Europeanness }\end{array}$ & $54 \%$ & $64 \%$ & $60 \%$ \\
\hline $\begin{array}{l}\text { Sees that ECOC events should represent a lot or very } \\
\text { much Europeanness }\end{array}$ & $64 \%$ & $74 \%$ & $72 \%$ \\
\hline
\end{tabular}

Levels of education also affected how respondents answered the open questions on the representation of Europeanness in the ECOC events. This was explored using thematic codes, based on the themes listed in the Table 4.1. We calculated how many of these codes were included in each open response on Europeanness in the events. Many of the respondents found difficult to describe Europeanness and did not, thus, answer the open questions regarding it. We considered, however, these 'empty answers' as meaningful data and included them in our calculations with a number zero. The more educated the respondents were, the more often they answered the open questions and the 
TABLE 7.5 Means of the number of different ways of perceiving Europeanness in the ECOC events given by respondents in different educational groups in Pécs, Tallinn and Turku, including empty answers $(A=$ comprehensive or elementary school, $\mathrm{N}=45$; $\mathrm{B}=$ vocational course or degree or in-job training, $\mathrm{N}=110 ; \mathrm{C}=$ high school, $\mathrm{N}=462$; $\mathrm{D}=$ polytechnic or other higher vocational education, $\mathrm{N}=163 ; \mathrm{E}=$ bachelor's degree, $\mathrm{N}=215 ; \mathrm{F}=$ master's degree, $\mathrm{N}=340 ; \mathrm{G}=$ doctoral degree, $\mathrm{N}=36$ )

\begin{tabular}{lcccccccc}
\hline & A & B & C & D & E & F & G \\
\hline $\begin{array}{l}\text { Number of different ways to perceive } \\
\text { Europeanness in the Ecoc events }\end{array}$ & 0.40 & 0.47 & 0.59 & 0.60 & 0.64 & 0.70 & 0.81 \\
\end{tabular}

more broad and varied descriptions they gave of how they perceived Europeanness in the events (Table 7.5).

Similarly, the EHL data revealed that notions of feeling European or being able to describe ideas about what Europe and the 'European' represents was linked with the interviewees' educational background (see Table 7.6). People who did not have a higher education struggled more frequently with describing notions of Europe, while interviewees with an academic background had greater linguistic and cognitive competence (and courage) to describe abstract concepts, and hence to explain what Europe and European identity might mean. Interviewees with a university education seemed to feel strongly European more often but, at the same time, they more frequently referred to both positive and negative associations with 'European identity'. Interviewees with a higher education more often described Europe as being open-minded, borderless, culturally and linguistically diverse, tolerant, and guaranteeing human rights and freedoms. However, many of them found the term 'identity' problematic and negatively connoted with exclusion, as implied in our findings in relation to age groups. From their studies, they were familiar with the rejection of the concept as too exclusionary and limiting. However, this did not affect their general sense of belonging to Europe, feeling European, and belief that Europeans from different cultural and ethnic backgrounds had things in common. This rejection of the term identity did not reveal the interviewees' relationship to the EU; in fact, most of them identified with the Union's political and economic goals.

Our analysis of the EHL data suggests that visitors with a higher education tend to feel a higher level of belonging to Europe, but their appreciation of the $\mathrm{EU}$ is based on multiple and diverse factors, including personal experiences, such as mobility, international work environments, bicultural partnerships, or mixed family backgrounds. Many of the interviewees who held academic degrees had had more opportunities for mobility and had spent some time 
abroad more frequently than the interviewees who had not gone to university. Furthermore, interviewees who had a higher educational background judged their transnational mobility experiences more positively $(67 \%)$ and also were more likely to work in international or multilingual environments than those who had a basic education or vocational training (50\%). Such diverse experiences can be assumed to impact on these interviewees' feeling of being European and their ability to describe what they viewed as European.

TABLE 7.6 Notions on European identity and feeling European in relation to education level among EHL visitors from EU countries, Russia, Switzerland, and Ukraine (A = basic education, high school, or vocational training, $\mathrm{N}=47$; $\mathrm{B}=$ higher education, bachelor's, master's, or doctoral degree, $\mathrm{N}=177$ )

A

Strongly feels European

Feels both European and membership of a specific nation, $59 \% \quad 65 \%$ region, or city

Does not feel European $17 \% \quad 23 \%$

Positive associations with the concept of European identity $24 \% \quad 8 \%$

Neutral associations with the concept of European identity

Negative associations with the concept of European identity $16 \% \quad 20 \%$

Other associations with European identity (e.g. views that it is a

$64 \% \quad 57 \%$

$4 \% \quad 8 \%$

project, still needs elaboration, or may emerge only in the future)

Is able to describe what European identity is

$16 \% \quad 15 \%$

Does not think that European identity exists

$49 \% \quad 61 \%$

$19 \% \quad 10 \%$

\subsection{National Background}

In all three case studies, most of the interviewees were EU citizens. In the ECOC case study, the majority of the respondents originated from three host countries in Central, Eastern, and Northern Europe; Hungary, Estonia, and Finland. The ECC project involved university students from six Western European countries; Belgium, France, Germany, Italy, Luxembourg, and Portugal. West European interviewees dominated the EHL data set, which was partly due to the higher mobility of visitors from some West European countries. For instance, at almost all EHL sites we interviewed Dutch, French, or German tourists. In total, we interviewed E HL visitors representing 34 nationalities (see Annex 1). The selection of the EHL sites for our fieldwork was based on the specific, predetermined criteria of our research project (see Lähdesmäki et al. 
2020): the year of awarding the Label, the site's theme, our linguistic competences, and the need to balance the sites on a North-South / East-West axis. As a result, six of the selected eleven EHL sites were situated in Western (and core) EU member states. Hence, the majority of our EHL interviewees were from Western European countries, most notably from Germany (16\% of total visitor numbers), France ( $15 \%)$, the Netherlands (15\%), Belgium (14\%), Italy $(10 \%)$, and Austria (7\%) (see Table 7.7).

TABLE 7.7 Frequency and percentage of nationalities among all E HL visitors from EU countries, Russia, Switzerland, and Ukraine $(\mathrm{N}=230)$

\begin{tabular}{|c|c|c|c|c|c|}
\hline Nationality & $\begin{array}{l}\text { Total } \\
\text { number } \\
\text { of visitors }\end{array}$ & $\begin{array}{l}\text { Total } \\
\text { percentage } \\
\text { of visitors }\end{array}$ & Nationality & $\begin{array}{l}\text { Total } \\
\text { number of } \\
\text { visitors }\end{array}$ & $\begin{array}{l}\text { Total } \\
\text { percentage } \\
\text { of visitors }\end{array}$ \\
\hline Austria & 16 & $7 \%$ & Russia & 1 & $<1 \%$ \\
\hline Belgium & 33 & $14 \%$ & Slovakia & 1 & $<1 \%$ \\
\hline Czech Rep. & 1 & $<1 \%$ & Spain & 1 & $<1 \%$ \\
\hline Denmark & 3 & $1 \%$ & Sweden & 2 & $1 \%$ \\
\hline Finland & 3 & $1 \%$ & Switzerland & 2 & $1 \%$ \\
\hline France & 35 & $15 \%$ & UK & 15 & $7 \%$ \\
\hline Germany & 37 & $16 \%$ & Ukraine & 2 & $1 \%$ \\
\hline Greece & 2 & $1 \%$ & Austrian-Polish & 1 & $<1 \%$ \\
\hline Ireland & 2 & $1 \%$ & Dutch-American & 1 & $<1 \%$ \\
\hline Italy & 22 & $10 \%$ & French-German & 1 & $<1 \%$ \\
\hline Luxembourg & 1 & $<1 \%$ & Russian-French & 1 & $<1 \%$ \\
\hline Netherlands & 35 & $15 \%$ & Swedish-Dutch & 1 & $<1 \%$ \\
\hline Poland & 9 & $4 \%$ & $\begin{array}{l}\text { Hungarian-British- } \\
\text { German }\end{array}$ & 1 & $<1 \%$ \\
\hline Portugal & 1 & $<1 \%$ & & & \\
\hline
\end{tabular}

In all our data, Europe is often identified with 'Western' Europe and reflects a certain bias to reproduce ideas and notions of citizens from core Western EU member states. These narratives may significantly differ from those of citizens from Central and East European states. The wealth of backgrounds in the EHL data allowed us to observe considerable differences in the discourses about Europe and the 'European' from different parts of Europe. While for some Western European interviewees, East European countries served as examples of the 'European Other', the vast majority of all interviewees and respondents 
in the case studies - EU citizens and tourists from non-EU countries alike associated the 'other' with non-European contexts. For them, the USA, Australia, Africa, Asia, and South America represented different political and social models and opposing examples of what constituted Europe and the 'European'.

The EHL visitors pinned specific social meanings on Europe, very similar to the official EU value discourse, and often interpreted the EU in terms of a social welfare model. Moreover, they often understood Europe as a social construction and closely associated it with the EU and its legal and political provisions. As a result, traditional and historical constructions of ingroups and outgroups, based on national and ethnic differences and enmities between European countries, were replaced by new categories of inclusion and exclusion. The new outgroups were usually situated or viewed as originating from outside Europe or the EU. Nevertheless, the visitors expressed historically and culturally embedded differences in how they understood the significance of national sovereignty and the citizens' relationship to the EU, which influenced their ways of constructing (or not constructing) belonging to Europe. In this, our data reflects similar findings from earlier studies of political discourses and interpretations of European integration in European countries (see Marcusssen et al. 1999; Risse et al. 1999; Breakwell 2004).

Quantifying the qualitative responses in our EHL data enabled us to compare attitudes towards Europe and feeling European based on a four-point scales (feel strongly European / feel also European in addition to national or other scalar allegiance / do not feel European / cannot say or not answered) in relation to the seven biggest visitor groups: Germany, France, the Netherlands, Belgium, Italy, Austria, and the UK (see Table 7.8). Italian interviewees (88\%) and Austrians (81\%) felt most strongly European, followed by Germans $(75 \%)$ and French interviewees $(73 \%)$. At the lower end of this group were Belgian (5०\%), British (5०\%), and Dutch (47\%) visitors. Dutch visitors had the largest numbers who did not feel European (31\%), followed by British visitors $(17 \%)$ and Belgian and Austrian visitors (13\% each). In contrast, relatively few French and German interviewees ( $8 \%$ and $3 \%$, respectively) did not feel European and not a single Italian interviewee expressed not feeling European at all.

When looking at the answers about feeling European among visitors from Ukraine, Switzerland and Russia, we noticed that they predominantly strongly felt European $(6 \circ \%)$ or also felt European $(40 \%)$ in addition to feeling allegiance to their home countries. However, their total number was too small (see Table 7.7) to draw any valid conclusion or generalize our findings. While Poles constituted a comparatively small proportion of the interviewed visitors to the EHL sites, they were the biggest group among Central and East European nationals. Of the Polish interviewees, $17 \%$ expressed strongly feeling European 
versus $83 \%$ feeling both Polish and European. While the first figure was lower than for nationals of West European countries, the second figure was much higher than among West European nationals. Furthermore, not a single Polish interviewee avoided addressing the issue of feeling European or claimed not to feel European, showing that this issue had some relevance to all of them.

TABLE 7.8 The seven biggest nationality groups in relation to their notion of feeling European among interviewed EHL visitors from EU countries, Russia, Switzerland, and Ukraine (those who were asked/answered)

\begin{tabular}{lcccc}
\hline Nationality & $\begin{array}{l}\text { Strongly feels } \\
\text { European }\end{array}$ & $\begin{array}{l}\text { Feels also } \\
\text { European }\end{array}$ & $\begin{array}{l}\text { Does not feel } \\
\text { European }\end{array}$ & $\begin{array}{l}\text { Unable } \\
\text { to say }\end{array}$ \\
\hline Austria & $81 \%$ & $6 \%$ & $13 \%$ & $\circ \%$ \\
Belgium & $50 \%$ & $29 \%$ & $13 \%$ & $8 \%$ \\
France & $73 \%$ & $15 \%$ & $8 \%$ & $4 \%$ \\
Germany & $75 \%$ & $22 \%$ & $3 \%$ & $\circ \%$ \\
Italy & $88 \%$ & $13 \%$ & $\circ \%$ & $\circ \%$ \\
Netherlands & $47 \%$ & $16 \%$ & $31 \%$ & $6 \%$ \\
UK & $50 \%$ & $33 \%$ & $17 \%$ & $\circ \%$ \\
\end{tabular}

The quantification of the qualitative data from the E HL case study supported our reading of the interview data: that for most Europeans we interviewed, feeling European was an important issue. At the same time, the interviews revealed that feeling European is very complex. In some cases, Europe and belonging to Europe were interpreted as desirable but not necessarily linked with EU membership, whereas other visitors, particularly those who positioned themselves as feeling both European and citizens of an EU member state, often referred to the membership of their home country in the EU. Considering the small number of interviewees, we cannot draw strong conclusions but our data enables us to reflect on and interpret the responses in their wider (national, cultural, historical, societal) context.

Despite their rather skeptical attitude towards Europe, as exemplified in their comparatively low scores of feeling European $(47 \%)$ and high scores of not feeling European (31\%), Dutch interviewees displayed a curious example of in-betweenness. Depending on the EHL site at which they were interviewed, Dutch visitors differently integrated Europe and notions about the 'European' in their construction of belonging. At Camp Westerbork, we interviewed many local Dutch visitors and often noticed that they expressed Eurosceptic 
narratives. However, Dutch visitors interviewed outside the Netherlands felt more connected to Europe and more often emphasized feeling European. As we observed that other interviewees with a higher degree of mobility often viewed Europe and belonging to Europe more favorably than people who were interviewed in their home countries, we decided to scrutinize mobility more closely as a relevant factor in interviewees' and respondents' perceptions of Europe. The case studies (Chapters 4-6) highlighted how personal experiences of mobility impacted on participants' answers and views; we return to this issue towards the end of this chapter.

The fact that Italian visitors strongly affirmed feeling European seemed surprising at first glance, given the rise of the populist party Lega Nord and the Cinque Stelle movement in Italy at the time of the EHL fieldwork. However, our results reflected the EH L site where most Italians were interviewed, which was a museum to one of the founding figures of the European Community and Union, Alcide de Gasperi. The majority of the visitors at this site were Italian students at university and in their final year at high school who participated in a project about Europe. The other Italian visitors were interviewed at EHL sites abroad, and we assume that the same effect of mobility, as observed among mobile Dutch visitors, applied to them as well.

Most Belgian visitors were interviewed at the EHL site in Belgium, which may have contributed to the aforementioned scores on strongly feeling European $(5 \circ \%)$ and not feeling European (13\%). These answers may reflect a double-edged attitude to the European project in the Belgian public. Support for EU integration is not equally strong in all language communities across Belgium but reflects the divergent demands of different political forces, parties, and poles (see Sinardet 2013). Migration was addressed in many interviews we conducted in Belgium. However, increasing public opposition in Belgium to the EU's social and economic agenda, in particular regarding further EU enlargement, coupled with concerns about social inequalities for Belgian nationals arising from inner-European mobility and migration to Europe from other countries, seem to reduce the willingness to support European integration and European solidarity (see Baute et al. 2019; Brack and Crespy 2019).

According to the qualitative analysis of our E HL data, UK visitors were more often skeptical about belonging to Europe and spoke more critically about ideas of solidarity and unity within the EU than visitors from other European states, which confirms the findings of earlier studies (e.g. Knopf 2002; Wyn Jones et al. 2013; Jeffery et al. 2014; Ormston 2015). Our interviewees from England tended to emphasize an antagonism between their sense of nationality (Englishness) and Europeanness, which was addressed in many interviews. The contrast between these two poles of belonging constructed their discourse 
of Europe and the European, and often amounted to feeling more distant from Europe. Scottish visitors also often distinguished themselves from the English. These interviewees often constructed a closer sense of connection and belonging to both Europe and the EU. In principle, our findings confirm the different and divided positions towards the EU revealed in UK voting behavior during the referendum on leaving the EU (June 2016) and the parliamentary elections (December 2019).

Europe and the EU resonated in a different way for the interviewed German visitors to EHL sites (both in Germany and abroad). They constructed a link between feeling German and being European, in which Europe and a concern for preserving European unity seemed to be strongly embedded in their understanding of belonging. The discourse of these interviewees strongly reflected the post-war, West German political discourse on overcoming the country's nationalist and militarist history (see Risse 2004, 252) - in contrast to the discourse of many UK interviewees. This discourse favored European belonging over German identity. While most of the German interviewees were West Germans, the few East German interviewees seemed to share this discourse but as it turned out, they either resided in West German federal states or had a critical attitude to the former German Democratic Republic.

The answers of the ECOC respondents in Pécs, Hungary and interviews with the Polish EHL visitors to the European Solidarity Centre in Gdańsk, Poland partly reflect the openly nationalistic turn in Polish and Hungarian politics in the past decade. The current attempts to rewrite Hungary's 'golden past' conflicts with the experiences of the early 199os, when Hungary strove to join 'Europe' and to 'become European'. Similarly, the national populistic policy of the Law and Justice (PiS) party has recently led the government in Poland to openly and strongly collide with EU politics and values, resulting in a European Court of Justice ruling against Polish judicial reform. The Polish interviewees at the European Solidarity Centre partly referred to the critical legal and political situation in their country and, depending on their personal positions, this influenced their views on Europe and the 'European'.

It is noteworthy that the few people who said they had dual citizenship or an ethnically mixed family background always felt strongly European, suggesting that multiple ethnic, national, and cultural allegiances and everyday transnational practices can facilitate a stronger allegiance to Europe (see Čeginskas 2016). Our findings confirm the importance of social experiences for making Europe to an important object of identification, as also proposed by the transactionalist theory, which suggests that patterns of transnational interaction and communication can lead to a growing sense of community among citizens, and hence increase support for further political integration 
(see Deutsch 1957, 1966, 1969, 34-35). However, our quantified findings about feeling or not feeling European do not aim to represent the actual sentiments and attitudes of European citizens in their respective countries. Moreover, our interviewees sometimes revealed rather unexpected answers that needed contextualization. For instance, the only person from Luxembourg who was interviewed at an EHL site did not feel European. The interviewee addressed the fear of small countries becoming politically crushed between big powers but it became obvious during the interview that the visitor was having an 'off day', which affected the interview at large. If the same person had been interviewed at another time, the answer about feeling European could have been different. This interview crystallized the fact that all research dealing with informants' opinions, views, experiences, and feelings are always situational and context-dependent, and may change.

Far from wishing to essentialize our findings about notions of Europe and feeling European in relation to the nationality of the visitors, these examples reveal how nation-specific contexts and personal disposition based on culturally and historically embedded notions become relevant for understanding the responses in our data. Europeanization is not an isolated process: when addressing and examining Europeanization, it is important to pay attention to processes of regional, international, or supranational integration and to processes of globalization, as relations and interaction between states. A transnational approach must use different levels of analysis, namely, the local, the national, the European, and the global level, and, equally, the interplay between these levels must also be analyzed, as connecting points for transnational transactions can be found at each level (see Kuhn 2011; Faist 2014; Delhey et al. 2014). Similarly, the analysis of the ECOC data in relation to gender showed interesting regional differences, which appeared to intersect with various social aspects, such as gender and age. For historical reasons, the notion of Europe is understood differently in today's states, which have developed as sovereign entities over centuries than in those, which were part of larger multi-ethnic empires in the years leading up to World War I. In addition, experiences with World War II and with the Socialist regime until 1989/1991 forged different mnemonic communities in West European and Central and East European countries. These historical experiences contributed to affect both their divergent understandings of the past and of their contemporary positions in the EU (see Mälksoo 2009, 2014). Hence, a notion of belonging to the EU - also in terms of a federal model of cohesion - can be interpreted against the fact that half of the twentieth-century these countries have been either occupied by the Soviet Union or situated in the Soviet bloc. This period of forced belonging affects their current notion of holding a liminal position 
within EUrope and is a factor in the increased nationalism in states like Poland and Hungary today. While West Germany had to undergo a complete reorganization and face its nationalistic past after World War II, other Western states, and later the states, which regained independence when the Soviet Union collapsed, continued to draw on their national past, and this resonates in their citizens' views and attitudes.

Similarly, the public debates on the current state of the EU highlight the many crises the Union is facing. People draw different conclusions from this: while some foresee disintegration of the EU, others assume that the Union's future lies with even closer integration. However, the entanglement of national and European discourses in our participants' answers makes it difficult for us to distinguish what they mean by Europe, as different interpretations of the concept are interrelated and mutually influence people's perceptions. Therefore, the relation between the EU and its citizens needs to be examined in context - which may yield contradictory findings.

\subsection{Location and Thematic Focus}

The geographical locations and the thematic narrative of the researched EHL sites both matter for our pool of interviewees and their answers on Europe. Some EHL sites hold a different attraction to local or national visitors than to foreign tourists. For instance, the Great Guild Hall in Tallinn is more frequented by foreign visitors than by local Estonians who avoid the touristic old town where it is located. During our fieldwork, we did not manage to interview a single Estonian visitor to the Great Guild Hall. Other sites - such as Hambach Castle, Robert Schuman House, Alcide de Gasperi House Museum, or Carnuntum Archaeological Park - appeared to be of greater interest to local or national visitors than to foreigners. Furthermore, the specific themes of some EHL sites (e.g. Franz Liszt Academy of Music) did not necessarily attract a mainstream but rather a select audience.

The respondents interpreted our interview and survey questions in terms of the thematic narratives set by the respective exhibition at the heritage site, cultural event, or project, which consequently affected their views and answers. For instance, at EHL sites situated in border areas or near national borders - such as Hambach Castle, Lieu d'Europe, Robert Schuman House, Carnuntum Archaeological Park, or Alcide de Gasperi House Museum visitors more often referred to borders and explained the impact of open borders on their lives. At Camp Westerbork, a former transit camp to Auschwitz and other extermination camps, visitors discussed mobility in critical terms, while at the Sagres Promontory they discussed nature and the environment, which they experienced there, and in Gdańsk most visitors referred to Eastern 
Europe. The thematic influence on interview answers was most noticeable at the home museums of EU founding figures (Robert Schuman and Alcide de Gasperi) and Lieu d'Europe in Strasbourg, an exhibition space on the EU institutions and the historical development of the EU. The experience of these sites often prompted visitors to relate their answers to notions of crisis in Europe or the relevance of personal involvement for transforming and advancing the European project but they also often expressed strongly feeling European, as the previous section showed. In this respect, the thematic narrative and the extent to which a site or event was visibly associated with Europe impacted on how visitors approached and understood our questions, and on the way they answered.

Although the thematic narration of a site or cultural event provided an initial trigger for answering our questions, it did not necessarily constrain the interviewees' narratives. This could be observed at some EHL sites, such as the Mundaneum in Belgium, where the exhibition on secret codes did not provide most visitors with any explicit relation to Europe or European cultural heritage. Interviewees moved freely in and out of the spatiotemporal and emotional frame suggested by the site's narrative on secret codes. Equally, for some visitors, our questions stimulated long narratives, while others provided no more than a short reply. Chapters 4-6 discussed how the EU's politics of belonging intertwines with individual and collective efforts and aspects that situate humans in time and space. Our case study participants revealed different processes of creating (non-)belonging and our analysis of the data showed that these processes are shifting, multiple, continuously constructed, and context-bound, enriched by personal narratives, positions, and experiences.

\subsection{Personal Engagement in Cultural Activities}

In our EHL fieldwork, we asked our interviewees about their notions of the importance of cultural heritage in general and European cultural heritage in particular (see Lähdesmäki et al. 2020). The responses enabled us to see a strong connection between personal views on the cultural heritage and imagination of Europe as a cultural space based on specific discourses. However, we did not ask the EHL interviewees in detail about their engagement with culture per se. In contrast, the questionnaire survey in the ECOC case study allowed us to specifically analyze respondents' willingness to engage in cultural activities and their level of immersion, which revealed that this factor played a role in their views on the 'European'. One question in this survey was: 'How often do you participate in difference cultural events (such as festivals, concerts, exhibitions, theatre plays)?' The analysis showed that culturally active respondents more often identified with Europeanness and had more positive impressions 
of it than the less active ones. They also tended to connect the ECOC events with Europe more often than the culturally less active respondents, and considered it important to create Europeanness through these events (see Table 7.9). Activeness in cultural participation also affected how respondents answered the open questions on the representation of Europeanness in the ECOC events. This was explored in the same way as in the case of education (see Table 7.5). The more culturally active the respondents were, the more often they answered the open questions and the more broad and varied descriptions they gave of how they perceived Europeanness in the events.

TABLE 7.9 Views on Europeanness among respondents from Pécs, Tallinn and Turku in relation to their activeness in cultural participation $(\mathrm{A}=$ hardly ever $\mathrm{N}=18$; $\mathrm{B}=$ once a year or less, $\mathrm{N}=53 ; \mathrm{C}=$ a couple of times a year, $\mathrm{N}=321 ; \mathrm{D}=$ every other month, $\mathrm{N}=244 ; \mathrm{E}=1-3$ times a month, $\mathrm{N}=555 ; \mathrm{F}=$ once a week or more, $\mathrm{N}=209$ ), including the mean number of ways in which they perceived Europeanness in the EcOC events

\begin{tabular}{|c|c|c|c|c|c|c|}
\hline & A & B & $\mathrm{C}$ & $\mathrm{D}$ & E & $\mathbf{F}$ \\
\hline Identifies a lot with Europeanness & $29 \%$ & $40 \%$ & $38 \%$ & $36 \%$ & $44 \%$ & $54 \%$ \\
\hline $\begin{array}{l}\text { Positive or very positive impressions of } \\
\text { Europeanness }\end{array}$ & $31 \%$ & $6 \circ \%$ & $72 \%$ & $73 \%$ & $75 \%$ & $83 \%$ \\
\hline $\begin{array}{l}\text { Sees that ECOC events represent } \\
\text { Europeanness a lot or very much }\end{array}$ & $37 \%$ & $67 \%$ & $56 \%$ & $62 \%$ & $61 \%$ & $67 \%$ \\
\hline $\begin{array}{l}\text { Sees that ECOC events should represent } \\
\text { Europeanness a lot or very much }\end{array}$ & $50 \%$ & $77 \%$ & $67 \%$ & $70 \%$ & $72 \%$ & $79 \%$ \\
\hline $\begin{array}{l}\text { Number of different ways of perceiving } \\
\text { Europeanness in the EcOC events }\end{array}$ & 0.00 & 0.34 & 0.43 & 0.64 & 0.69 & 0.77 \\
\hline
\end{tabular}

The questionnaire data has been previously analyzed by creating a Cultural Competence Index based on the respondents' level of education, immersion in cultural events in general, immersion in the ECOC events, immersion in the organization of the ECOC events, and source of livelihood in the arts and cultural sector (Lähdesmäki 2014b). This index aimed at enabling the analysis of the open responses guided by Bourdieu's $(1984,1987)$ notion of cultural capital. The study indicated that the respondents with a high score in Cultural Competence Index related various contemporary phenomena and issues to the representation of Europeanness. In addition, they were more likely to interpret Europeanness in terms of international connections, which they recognized between the host city, its cultural scene, and Europe, and in relation to the 
cultural features they considered as common to Europe. In general, describing Europeanness as a shared cultural identity based on common cultural grounds was relatively rare in the data. Only some respondents with a very high score in the above-mentioned Index related the display of historical issues to Europeanness.

Based on the analysis of the ECOC case study in particular, we suggest that willingness to (actively) engage with cultural activities is another element of negotiating belonging that affects attitudes towards Europe. People who are willing to visit and immerse themselves in certain cultural events or sites marked as European might be more willing to construct belonging to Europe. For instance, we assumed that participants in the ECC project were interested in issues and themes related to Europe and the EU, which was behind the project. The interviewees' answers were therefore more likely to confirm or possibly strengthen the interviewee's existing set of attitudes and ideas. We were not able to analyze the connection between personal engagement in cultural activities and stronger sense of belonging to Europe in the EHL data, since the majority of the interviewed visitors were not aware that the Label had been awarded to the EHL site they were visiting (see Lähdesmäki et al. 2020; Čeginskas 2019). Based on this data, we suggest that personal engagement in European-themed cultural events and activities is more likely to be interconnected with various reasons and motivations.

\subsection{Mobility}

In the three case studies, our interviews and survey did not include specific questions on mobility, movement, and migration but mobility crystallized as an important theme and social phenomenon to which people referred in manifold ways during the qualitative interviews and in survey responses. We understand mobility experiences referring to experiences with cross-border mobility, which influence people's individual transnational practices in terms of "individual ties, interactions, and mobility across borders" (Kuhn 2015, 31) that enable them to develop specific transnational skills or affect their choices in life (see Favell 2008; Kuhn 2011).

Mobility experiences equally affected visitors' views on belonging to Europe, as we particularly noted in our EHL data set. While not all interviewees referred to personal experiences of transnational mobility, or mentioned explicitly their lack of them in the interviews, $29 \%$ of the EHL visitors (68 out of a total of 230) across all age groups integrated their personal experiences with various forms of mobility in their answers (see Table 7.10). These experiences included long-term migration experiences, periods studying or working abroad, extensive and frequent travels, or possessing summer cottages abroad, 
all of which enabled the interviewees to learn more and talk about other people and practices. We noticed that if an interviewee had personal experiences of mobility, she or he was more likely to refer to mobility and to relate it to issues such as European heritage, identity, and belonging. This suggests that people consider their personal mobility experiences as having a profound impact on themselves, their views and positionings in the world, and as giving them another perspective to that of those who did not move. Our findings suggest that transnational mobility experiences are a marker of difference akin to other social and cultural factors, such as age, gender, or education (see Favell 2008; Faist 2014, 212).

The group of interviewees aged 66 and over addressed personal mobility experiences most ( $72 \%$ of this age group); they referred to extensive travels or long-term stays abroad for professional reasons, but also to memories of displacement during or right after World War II. The middle-aged interviewees made the least reference to their personal mobility experiences (or lack of them) in their answers $(43 \%)$, while more than half of the interviewees under the age of 35 years referred to such experiences. There was an equally high number $(92 \%)$ of interviewees in the young and middle-aged age groups who linked their answers to personal mobility experiences (see Table 7.10). Middle-aged persons often highlighted extensive travels or longer professional stays abroad. In contrast, younger people more frequently referred to exchanges (most notably Erasmus) or internships abroad, which testifies to the rise and attractivity of such programmes over the recent decades (Cairns 2017). They often explained their motivation for participating in exchanges with an increased interest in encountering people from different countries and learning more about their lifestyles in terms of 'seeing and getting to know the world'.

TABLE 7.10 Personal mobility experiences (explicit mentions of a stay abroad; Erasmus or equivalent; migration experience; extensive travel, $\mathrm{N}=68$ ) versus non-mobility experiences (explicit mentions of being non-mobile, $\mathrm{N}=4$ ) among EHL visitors from EU countries and from Russia, Switzerland, and Ukraine in relation to age groups

Age group

Mentions being mobile

Mentions being non-mobile

$\begin{array}{lrr}18-35 & 92 \% & 8 \% \\ 36-65 & 92 \% & 8 \% \\ 66+ & 100 \% & \circ \% \\ \text { Total } & 94 \% & 6 \%\end{array}$


We noticed that mobility duration often affected the extent to which the interviewees felt European. People who mentioned longer stays abroad or who travelled extensively and frequently in Europe and other parts of the world more often expressed that they strongly felt European, and often found the national framework limiting for constituting belonging. In this respect, mobility strengthened self-reflection about who the 'others' are and transformed views on the issue of belonging by emphasizing its personal aspects. However, our data set included too few interviewees (just four visitors) who explicitly mentioned having no or not enough mobility experiences to draw any reliable conclusion based on how limited mobility may affect people's sense of being and feeling European.

We also noticed that a great number of the EHL interviewees with transnational mobility experiences judged mobility as a (even very) positive experience (see Table 7.11). Within this, we perceived age-related differences: young adults were the most likely to view mobility positively. While the oldest age group often had positive associations with mobility, they differentiated more carefully between voluntary (positive) and forced (negative) movement. Happy memories of meeting one's future partner abroad or residing and working in different countries were contrasted in the same interviews with experiences of displacement and deportation during and shortly after World War II. Some interviewees also spoke critically about mobility in the current political climate in Europe and linked it with the humanitarian crisis of receiving refugees in Europe. Others, particularly middle-aged visitors, also referred to negative effects of inner-European migration and revealed concerns for safeguarding social standards and rights. In contrast, the younger generation often

TABLE 7.11 Mobility associations in relation to age group among E HL visitors from EU countries, Russia, Switzerland and Ukraine in four groups (positive $\mathrm{N}=90$, neutral $\mathrm{N}=43$, negative $\mathrm{N}=2$, both positive and negative associations $\mathrm{N}=8$ )

\begin{tabular}{|c|c|c|c|c|}
\hline Age group & $\begin{array}{l}\text { Positive } \\
\text { associations with } \\
\text { mobility }\end{array}$ & $\begin{array}{l}\text { Neutral } \\
\text { associations with } \\
\text { mobility }\end{array}$ & $\begin{array}{l}\text { Negative } \\
\text { associations with } \\
\text { mobility }\end{array}$ & $\begin{array}{l}\text { Both positive } \\
\text { and negative } \\
\text { associations }\end{array}$ \\
\hline
\end{tabular}

$\begin{array}{lcccc}18-35 & 70 \% & 23 \% & 2 \% & 4 \% \\ 36-65 & 57 \% & 38 \% & 2 \% & 3 \% \\ 66+ & 60 \% & 27 \% & \circ \% & 13 \% \\ \text { Total } & 62 \% & 31 \% & 1 \% & 6 \%\end{array}$


viewed mobility and movement less critically and focused in their narratives on (recent) personal benefits and concrete experiences of privileged mobility.

Moreover, our analysis revealed that those interviewees who expressed positive associations with mobility also often strongly felt European $(72 \%$, see Table 7.12), which confirms mobility as an important factor and social phenomenon in both European integration and feeling belonging to Europe (see e.g. Favell 2008; Recchi and Favell 2009). Interpersonal relationships, travel, and exchanges across European countries contribute to deepening awareness of cultural diversity in Europe, which interviewees commonly viewed as an important and descriptive feature of what represents Europe. At the same time, individual mobility enables cross-border encounters and transnational interaction that often have the psychological effect of mitigating national boundaries or political, cultural, and social differences within Europe (see also Kuhn 2011), and thereby help individuals feel that they share commonalities with citizens of other European countries.

TABLE 7.12 Mobility associations in relation to feeling European (strong feelings $\mathrm{N}=122$; feeling several belongings $\mathrm{N}=41$; no feelings $\mathrm{N}=22$; unable to say $\mathrm{N}=5$ ) among EHL visitors from EU countries, Russia, Switzerland and Ukraine

Feeling European

Strongly feels Feels also Does not feel Unable European European European to say

\begin{tabular}{|c|c|c|c|c|}
\hline Positive associations with mobility & $72 \%$ & $21 \%$ & $4 \%$ & $4 \%$ \\
\hline Neutral associations with mobility & $50 \%$ & $28 \%$ & $19 \%$ & $3 \%$ \\
\hline Negative associations with mobility & ०\% & $50 \%$ & $50 \%$ & ०\% \\
\hline $\begin{array}{l}\text { Both positive and negative } \\
\text { associations with mobility }\end{array}$ & $71 \%$ & $29 \%$ & ०\% & ०\% \\
\hline Total & $65 \%$ & $24 \%$ & $8 \%$ & $3 \%$ \\
\hline
\end{tabular}

The ability to establish positive associations with (manifold forms of) mobility played a role across all age groups among those interviewees who strongly felt European, but it was a particularly important aspect among young interviewees as the interviews revealed (see Table 7.13). Younger interviewees often considered mobility as a right - and display of their personal freedom - that they took for granted, and which determined their space of movement and belonging. In this context, the European integration becomes a relevant factor for guaranteeing the continuation and extension of this right. 
TABLE 7.13 Positive associations with mobility according to age ( $\mathrm{N}$ in age groups from the youngest to oldest: 22, 21, 15, and 58) and strongly feeling European among E H L visitors from EU countries, Russia, Switzerland, and Ukraine

\begin{tabular}{lrrrr}
\hline Age group & $18-35$ & $36-65$ & $66+$ & Total \\
\hline $\begin{array}{l}\text { Strongly felt European and had positive } \\
\text { associations with mobility }\end{array}$ & $85 \%$ & $64 \%$ & $68 \%$ & $72 \%$
\end{tabular}

Our analysis suggests that the quality of mobility experiences affected the extent to which interviewees felt European. Similarly, the more positive associations with mobility the interviewees had, the better they were able to describe what European identity represented (see Table 7.14). While the people with the most mobility experiences in our data set, the interviewees aged 66 and over, expressed feeling European (74\%) the most (see also Table 7.3), they were often less able to describe what a European identity is. However, the older group contained the smallest number of interviewees with a higher education, which might have affected their ability to express their notions and thoughts on Europe and the European. European integration has increased over the past decades and through banal practices (Billig 1995) the ability to describe Europe has increased. The younger interviewees were born into a different framework and more readily adopted new practices than the middle-aged and

TABLE 7.14 Mobility associations and ability to describe European identity (able N = 106; unable $\mathrm{N}=55$; thinks it does not exist $\mathrm{N}=21$ ) in $\mathrm{EHL}$ visitors from $\mathrm{EU}$ countries, Russia, Switzerland, and Ukraine

\begin{tabular}{lccc}
\hline & $\begin{array}{l}\text { Is able to } \\
\text { describe } \\
\text { European } \\
\text { identity }\end{array}$ & $\begin{array}{l}\text { Unable to describe } \\
\text { European identity } \\
\text { but believes it } \\
\text { exists }\end{array}$ & $\begin{array}{l}\text { Thinks that } \\
\text { European } \\
\text { identity does } \\
\text { not exist }\end{array}$ \\
\hline $\begin{array}{l}\text { Positive associations with mobility } \\
\text { Neutral associations with mobility }\end{array}$ & $69 \%$ & $17 \%$ & $14 \%$ \\
$\begin{array}{l}\text { Negative associations with mobility } \\
\text { Both positive and negative }\end{array}$ & $50 \%$ & $40 \%$ & $13 \%$ \\
$\begin{array}{l}\text { associations with mobility } \\
\text { Total }\end{array}$ & $57 \%$ & $50 \%$ & $0 \%$ \\
\hline
\end{tabular}


older generations. The interviewees in the older two age groups had seen the implementation of new European symbols, such as the common currency and European citizenship, alongside existing national symbols and practices, as discussed in Chapter 6.

Mobility is an important social factor in the EU's politics of belonging and connects to practices of EU citizenship, processes of integration, and social equality concerns, making the context of mobility experiences important for the individual, too. Increasing mobility is a central aim of the EU cultural policy (see Chapter 2). Our findings reveal that mobility is an important phenomenon in constructing belonging and intersects with the interviewees' social locations. Diverse experiences of mobility, such as extensive travel, study exchanges, and migration for work or for love can make European citizens feel more European. Mobility often leads to meaningful relationships between people from different backgrounds. This enables learning about cultural and social practices that provide insight into Europe's cultural diversity, without it becoming viewed as a source of friction and new conflict. Among young people in particular, positive experiences of mobility increase their sense of belonging to Europe and to the EU as a political, economic, and socio-cultural entity. The analysis of our case studies confirms that mobility has become increasingly significant in recent decades. It stands for globalization and collective networking in both positive and negative ways - maintaining and increasing personal freedoms but deepening social inequalities between people. Transnational mobility experiences seem to construct a cleavage between mobile and less mobile EU citizens, creating new forms of social inclusion and exclusion based on citizens' unequal and stratified involvement in transnational interactions (Kuhn 2019, 1222; see also Faist 2014). Thus, it has an impact on the visitors' answers, and conditions their relationship to and understanding of Europe and the 'European'.

\section{References}

Baute, S., K. Abts, and B. Meuleman 2019. "Public Support for European Solidarity: Between Euroscepticism and EU Agenda Preferences?" Journal of Common Market Studies 57 (3): 533-55o. DOI: 10.1111/jcms.12833

Billig, M. 1995. Banal Nationalism. London, Thousand Oaks and New Delhi: Sage. Bourdieu, P. 1984. Distinction. A Social Critique of the Judgement of Taste. Routledge, London. 
Bourdieu, P. 1987. "The Forms of Capital." In Handbook of Theory and Research of the Sociology of Education, edited by J. G. Richardson, 241-258. New York: Greenwood Press.

Brack N., and A. Crespy 2019. "Belgium in Search of a Stance on Today's EU Integration Dilemmas." In The Future of Europe, edited by M. Kaeding, J. Pollak, and P. Schmidt, 5-8. Cham: Palgrave Macmillan. doi: 10.1007/978-3-319-93046-6_2

Breakwell, G. M. 2004. "Identity Change in the Context of the Growing Influence of European Union Institutions." In Transnational Identities. Becoming European in the $E U$, edited by R. K. Hermann, T. Risse, and M. B. Brewer, 25-39. Oxford: Rowman \& Battlefield.

Cairns, D. 2017. "The Erasmus Undergraduate Exchange Programme: A Highly Qualified Success Story?" Children's Geographies 15 (6): 728-740. doi: 10.1080/ 14733285.2017 .1328485

Citrin, J., and J. Sides 2004. "More than Nationals: How Identity Choice Matters in the New Europe." In Transnational Identities. Becoming European in the EU, edited by R. K. Hermann, T. Risse, and M. B. Brewer, 161-185. Lanham, Boulder: Rowman \& Littlefield Publishers.

Čeginskas, V. L. A. 2016. “I am Europe'. Experiences of Multiple Belonging." Ethnologia Fennica 43: 72-88. Accessed 23 April 2020. https://journal.fi/ethnolfenn/article/ view/65636/26505

Čeginskas, V. L. A. 2019. "The Challenges in Creating Visibility of European Cultural Heritage: A Case Study of the European Heritage Label." Ethnologia Fennica 46: 109-134.

Delhey, J., E. Deutschman, T. Graf, and K. Richter. 2014. "Measuring the Europeanization of Everyday Life: Three New Indices and an Empirical Application." European Societies 16 (3): 355-377. doi: 10.1080/14616696.2014.904916

Deutsch, K. W. 1957. Political Community and the North Atlantic Area: International Organization in the Light of Historical Experience. Princeton: Princeton University Press.

Deutsch, K. W. 1966. International Political Communities. New York: Anchor Books edition Garden City.

Deutsch, K. W. 1969. Nationalism and Its Alternatives. New York: Alfred Knopf Inc.

EC (European Commission). 2019. 2019 Report on equality between women and men in the EU. Brussels: European Commission. doi: 10.2838/395144

Faist, T. 2014. "On the Transnational Social Question: How Social Inequalities are Reproduced in Europe." Journal of European Social Policy 24 (3): 207-222. doi: 10.1177/ o958928714525814

Favell, A. 2008. Eurostars and Eurocities. Free Movement and Mobility in an Integrating Europe. Malden: Blackwell Publishing.

Jacquot, S. 2015. Transformation in EU Gender Equality. From Emergence to Dismantling. Gender and Politics Series. Houdsmills, and Basingstoke: Palgrave Macmillan. 
Jeffery, C., R. Wyn Jones, A. Henderson, R. Scully, and G. Lodge 2014. Taking England Seriously: The New English Politics. ESRC Scottish Centre on Constitutional Change. Accessed 7 January 2020. https://www.research.ed.ac.uk/portal/files/20030688/ Taking_England_Seriously_The_New_English_Politics.pdf

Knopf, H.-J. 2002. "Britain and European Integration between $195^{\circ}$ and 1993: Towards a European Identity?" PhD diss. Department of Social and Political Sciences. Florence: European University Institute.

Kuhn, T. 2011. "Individual Transnationalism, Globalisation and Euroscepticism: An empirical test of Deutsch's transactionalist theory." European Journal of Political Research 50 (6): 811-837. doi: 10.1111/j.1475-6765.2011.01987.x

Kuhn, T. 2015. Experiencing European Integration: Transnational Lives and European Identity. Oxford: Oxford University Press.

Kuhn, T. 2019. "Grand Theories of European Integration Revisited: Does Identity Politics Shape the Course of European Integration?" Journal of European Public Policy 26 (8): 1213-1230. doi: 10.108o/13501763.2019.1622588

Lähdesmäki, T. 2013. "Identity Politics of the European Capital of Culture Initiative and the Audience Reception of Cultural Events Compared." The Nordic Journal of Cultural Policy 16 (2): 340-365.

Lähdesmäki, T. 2014a. "The Influence of Cultural Competence on the Interpretations of Territorial Identities in the European Capitals of Culture." Baltic Journal of European Studies 4 (1): 69-96.

Lähdesmäki, T. 2014b. "European Capital of Culture Designation as an Initiator of Urban Transformation in the Post-socialist Countries." European Planning Studies $22(3): 481-497$.

Lähdesmäki, T., V. L. A. Čeginskas, S. Kaasik-Krogerus, K. Mäkinen, and J. Turunen. 2020. Creating and Governing Cultural Heritage in the European Union: The European Heritage Label. London: Routledge.

Lähdesmäki, T., and T. Saresma. 2014. "Reframing Gender Equality in Finnish Online Discussion on Immigration: Populist Articulations of Religious Minorities and Marginalized Sexualities." NORA-Nordic Journal of Feminist and Gender Research 22 (4): 299-313.

Lee, C., and R. Bideleux 20o9. "'Europe': What Kind of Idea?" The European Legacy 14 (2): 163-176.

Mälksoo, M. 2009. "The Memory Politics of Becoming European: The East European Subaltern and the Collective Memory of Europe." European Journal of International Relations 15(4), 653-68o. doi: 10.1177/1354066109345049

Mälksoo, M. 2014. "Criminalizing Communism: Transnational Mnemopolitics in Europe.” International Political Sociology 8 (1): 82-99. doi: 10.1111/ips.12041

Marcussen, M., T. Risse, D. Engelmann-Martin, H.-J. Knopf and K. Roscher 1999. "Constructing Europe: The Evolution of French, British and German Nation-State Identities." Journal of European Public Policy 6 (4): 614-633. 
Ormston, R. 2015. Disunited Kingdom: Attitudes to the EU across the UK. Accessed 7 January 2020. http://whatukthinks.org/eu/wp-content/uploads/2015/12/Analysis-paper -3-Disunited-kingdom.pdf

Recchi, E., and A. Favell, eds. 2009. Pioneers of European Integration. Citizenship and Mobility in the EU. Cheltenham: Edgar Elgar Publishing Inc.

Risse, T. 2004. "European Institutions and Identity Change: What Have We Learned?" In Transnational Identities. Becoming European in the EU, edited by R. K. Hermann, T. Risse, and M. B. Brewer, 247-271. Oxford: Rowman \& Battlefield.

Risse, T., D. Engelmann-Martin, H.-J. Knopf, and K. Roscher 1999. "To Euro or Not to Euro. The EMU and Identity Politics in the European Union." European Journal of International Relations 5 (2): 147-187.

Sinardet, D. 2013. "How Linguistically Divided Media Represent Linguistically Divisive Issues. Belgian TV-Debates on Brussels-Halle-Vilvoorde." Regional \& Federal Studies 23 (3): 311-33o. doi: 10.108o/13597566.2013.773895

Wyn Jones, R., G. Lodge, C. Jeffery, G. Gottfried, R. Scully, A. Henderson, and D. Wincott. 2013. "England and Its Two Unions: The Anatomy of a Nation and Its Discontents." Accessed 9 January 2020. http://www.ippr.org/publications/england-and-its-twounions-the-anatomy-of-a-nation-and-its-discontents 